\title{
Bladder Papillary Urothelial Carcinoma
}

National Cancer Institute

\section{Source}

National Cancer Institute. Bladder Papillary Urothelial Carcinoma. NCI Thesaurus. Code C7383.

An invasive or non-invasive papillary transitional cell carcinoma of the urinary bladder. It is classified as low - or high-grade. -- 2003 